Prof. Dr. Atila YÜKSEL

Aydın Adnan Menderes Üniversitesi

Turizm Fakültesi

atilayuksel@gmail.com

\title{
Pozitivist-Ampirik Araştırmalarda İnsan: Yanıltmacanın Dünü, \\ Bugünü ve Yarını - 2
}

\section{Özet}

Bilimsel araştırmalarda geçmişten geleceğe köprü kurmanın, çalışmanın niteliğini ve katkısını artırmanın anahtarı olan atıf geleneği son zamanlarda harareti giderek yükselen tartışmaların odağında. Atıf-bilimsel bilginin ilerleme rotasında öncü kaşiflerin bıraktıkları ayak izleri - malumatın nasıl keşfedildiğinin, nereden geldiğinin, test edildiğinin, yeniden değerlendirmelere tabi tutularak nasıl bilgiye dönüşerek perçinlendiğinin sağlam ve güvenilir göstergesiyken nasıl oldu da böylesine ateşli tartışmaların hedefi oldu? İçerdiği kavramsal, tasarımsal, yöntemsel, ölçümsel hatalardan dolayı prestijli dergilerde (SSCi), hem de sözde yüksek güvenlikli hakem değerlendirmesinden geçerek yayımlanmış çok sayıda makale yayından/dergiden geri çekilmekteyken, SSCI dergilerinden seçilen bazı yayınların replikasyon (yineleme) denemelerinde çalışma sonuçlarının yüzde yüz replike edilemediği ortadayken, sosyal bilimlerde üretilmiş bilginin \%95'inin geçerliliği sorgulanırken, yayından kaldırımış makalelerin hem de katlanan hızla hala olumlu alıntılanmaya devam etmesi atıf geleneği ve uygulamalarının geçerliliğiyle ilgili şüphe uyandırmakta. Atıf neyin göstergesi? Çalışmanın kalitesinin ve bilime katkısının mı? Atıf alan çalışmayı yapan bilim insanının araştırma ve yayın eylemiyle ne kadar meşgul olduğunun mu? Yoksa hiçbiri mi? Dayatılan genel başarı ölçütü konumundaki atıf geleneğinin çöküşte olduğundan hareketle bu çalışma akademik alanda varsa başarının yeniden tanımlanması gerektiğine işaret etmektedir.

\section{Giriş}

Yayın yapmak, özellikle primden dolayı rağbet edilen prestijli dergilerde yayın yapmak bir çok akademisyen için vazgeçilmez hedef. Ancak, artık yayın yapmamız yetmiyor. Markette, yayın reyonundaki ürünümüzün bir de raf ömrüne dikkat etmemiz gerekiyor. Hedef sadece yayın yapabilmek değil aynı zamanda giderek yükselen alıntılanma (atıf) sayısıyla prestij kazanmak, rafta uzun süre kalmak.

Alıntılanma bilimsel bilginin üretilmesi, test edilmesi, genişlemesi, süzülmesi, elenmesi açısından önemli. Bununla birlikte Gross ve Gross'un (1927) çalışmasıyla bilimsel araştırma literatürüne giren, hızla bilimsel çalışmanın öneminin ve bilim insanının prestijinin göstergesi olarak algılanmaya başlayan alıntılanma sayısı, alıntılama motivasyonu ve davranışı birçok yönden eleştiriye açık. Değişik türde atıf uygulamasının varığı söz konusu: Zorlama atıf, gereksiz atıf, negatif atıf, olumlu atıf, yüzeysel atıf, kayıtsız atıf, yanlış atıf, kendine atıf gibi çok farklı türleri bulunmakta.

Her ne kadar bilmediğimiz şeyin bizi incitmeyeceği söylense de sadece atıf geleneği değil gereğinden fazla önem atfedilen atıf sayılarını temel alan dergi etki faktörünün başarı göstergesi olarak kullanımı da çok şaşırtıcı sorulara ve keşiflere gebe (bakınız Archambault ve Larivière, 2009). Bu sorulardan bazıları: Alıntı sayısı çalışmanın niteliğinin tek göstergesi mi? Her alıntının ağırlığı eşit mi? Diğer bir ifadeyle her bir alıntı 
tek mi (eşsiz) yoksa bir mi (benzer)? Bütün sırrını yüksek alıntılanma sayısına bağlamış SSCi ideolojisi ve işçileri olarak bizler makalenin neresinin, nasıl ve kimin tarafından alıntılandığını önemsiyor muyuz? SSCi ideolojisinin mevcut uygulamasında makalenin hangi kısmının alıntılamaya dahil edildiğine dikkat edilmemesinin nedeni ekonomik mi? Yöntem, teori, bulgular, ya da ileri sürdüğünüz meydan okuma ya yanlışa destek olması için alıntılanıyorsa ne yapmalı? Kim kimi alıntılıyor hiç düşündünüz mü, bu bağlamda "network"lar yok mu? Amaç sayı mı yoksa bilindik/tanındık/alanında deyim yerindeyse rüştünü ispatlamış bilim insanlarınca alıntılanmak mı? Önemli bir diğer soru "alıntılayan bizi doğru alıntılıyor mu?" Ayrıca, eğer bilim eleştiriyle gelişiyorsa "alıntılanma neden daha çok pozitif ve neden daha az negatif?" Bulgunuza/yönteminize negatif alıntılama yapıldığında haberiniz oluyor mu? İlk negatif alıntılanmadan sonra makalenin alıntılanma ömrü nedir? Bu arada, negatif alıntılanması yüksek yazarlara pozitif alıntılanması yüksek yazarlara göre daha az prim ödemesi mi olmalı? Çalışmanın negatif alıntılanması onun yanlışlanması anlamına mı geliyor? Alıntılanan makalenin kendisini okumadan, orijinal makaledeki fikirlerini test etmeden, modelini bütünsel tekrar etmeden alıntılanan kaynağı kelime kopyacılığıyla kullanmak bilimi nasıl ilerletecek? Özetle, kör şekilde, kopyala ve yapıştır alıntılama geleneği neticesinde, alıntılama bağımlılığın arttığı, bunun makalenin içeriğini bir alıntılanma mezarına dönüştürdüğünü, daha da kısalan yazıya karşı daha da uzayan referans listesi gibi oldukça tartışmalı bir uygulamanın yaygınlaştığı görülmektedir. Fire ve Guestrin'in (2019) 120 milyon makaleyi analiz ettiği çalışması başarının göstergesi sayılan atıf uygulamasında taviz verildiğini, bir gösterge olarak geçerliliğinin riskli olduğunu ve faydasının azaldığını göstermektedir.

\section{Manipülasyon Borsası}

"Sosyal veya ekonomik bir ölçüt, politikalar ve stratejiler belirleyen bir hedef haline dönüşürse ölçme özelliğini yitirir" diyen Goodhart yasası ve benzer bir şekilde "sosyal karar verme mekanizmalarında kullanılan sosyal göstergeler ne kadar nicel olursa, bu göstergeler o derecede baskı altında kalacak ve denetlemeleri gereken süreçleri de o derecede bozacaktır" diyen Campell yasası uyarınca atıf gibi performansa dayalı ölçümler dönüşü olmaz yıkıma sebebiyet verecektir. Şöyle ki; bir akademisyenin yayın/atıf sayısı ne kadar başarıyı simgeler hale gelirse, yayın/atıf sayısını artırmak için önce iç ve dış baskı (teşvik nedeniyle) oluşacaktır. Akademisyenler göstergelerini iyileştirmek için muhtemelen şaibeli işlere bulaşacak, başarıyı simgeleyen gösterge (simulakır) faydalı bilim yapmanın/gerçeğin yerini alacaktır. Sonuçta fasarya bir bilim doğarak, başarıyı simgeleyen göstergeyi elde etme çabası bu göstergeyle ölçülen bilimi bozarak sonunu hazırlayacaktır. Diğer bir ifadeyle Goodhart ve Campell yasaları uyarınca bilimin ve prestijin ölçütü olan "atıfı sayma" giderek bilimin yozlaşmasına sebebiyet veren bir uygulamaya dönecektir. Akademisyenler, göstergeye ulaşmak için sistemin ödülünü ve takdirini kazanmak için akla dahi gelmeyecek eylemlere girişebilecektir.

Başarı kriteri atıf çöküştedir.

Ayrıca basitçe sayı sayma ve buna göre çalışmanın önemine/etkisine karar verme dört aşamalı "McNamara Yanılsamasına" gebe bir durumdur. Birinci sırada en kolay olanı ölçmek var (alıntıyı saymak gibi); takibinde kolay ölçülemeyen diğer her şeyi göz ardı etmek (çalışmanın hayata katkısı); kolay ölçülemeyen her şeyi önemsiz saymak ve kolay ölçülemeyen her şeyin yok olduğunu var saymakla karakterize olan bu yanılgı kabaca sadece nicel gözlemlere (veya ölçümlere) dayalı bir karar verme ve diğerlerini görmezden gelmek. Sayılara indirgeme, fayda yerine atıfı önemseyip bir de sayılarla ölçme yanılgıyı alevlendirmektir. Ölçmenin kendine has bozuklukları vardır. En basit olan "atıf sayısını ölçme eğilimi, çıktıdan daha çok girdileri ölçmek, ölçmeyle yormak, ölçmeyi 
çarpıtmak, ölçmeyi kişisel menfaate kurban etmek söz konusudur. Ölçülen şey ölçüm sürecinden etkileniyorsa o zaman ölçümden ve sonucunun güvenirliğinden bahsetmek mümkün müdür? Özelikle ölçümün objesi insansa ve insan kendini düşünen bir varlık olduğundan yani ölçüm sürecine bilinçle tepki vereceğinden, özellikle kendini/varlığını koruma bilincinden dolayı ölçümün geçerliliğini şüpheli hale getirmeyecek midir (atıf kardeşlikleri gibi)? Ölçüme ve ölçüte (measurement/criteria/metrics) odaklanmanın sonu oluşan aşırı sayısal odaklanma daha azın değil ama daha çoğun daha iyi olduğu sonucuna sebebiyet vermiyor mu?

Daha çok yayın ve daha çok alıntı iyi midir? "Yayınla ya da yok ol" günümüzde "yayınla ve yok ol' olmuştur. Bilindiği üzere araştırmalarının dahil olduğu genel yayın sisteminde makalelerin değerlendirme ve yayınlanma sürecinde saptanmayan; ancak, yayınlandıktan sonra fark edilen sorunlardan dolayı makalelerin bilimsel dergilerde yayından kaldırılma (retraction) hızı yükselmektedir. 1997'ye kıyasla 2018 yılında bu hızın 10 kat arttığı ifade ediliyor (Brainard ve You, 2018). Darsee Vakası, Reuben Vakası, Stapel Vakası, Kusnetsoz Vakası (Bar-İlan ve Halevi, 2017) ya da en son Rus Bilim Akademisinin 800 çalışmayla ilgili kararı. Giderek büyüyen bu sorun ne birkaç bilim dalıyla ne de birkaç ülkeyle sınırlı (Alrawadieh ve Zareer, 2019; Craig vd., 2020; Hesselmann, Graf, Schmidt ve Reinhart, 2017). Hız bilim dalına ve çalışma konusuna göre değişiklik gösterebiliyor. Sosyal bilimler kategorisinde bu makalenin hazırlandığı tarihlerde binlerce makale yayından geri çekilmiş durumda. Tartışmalı da olsa "Retractiondatabase" deki dağılım şöyle: Çin 10003; ABD 3930; Japonya 1079; İngiltere 835; Almanya 751; Türkiye 240; İsrail 95. 1970'li yıllardan itibaren, yayınlanan makalenin geçersizliğini kanıtlayan bilimsel sahtekarlık saptamaları sonunda yayından kaldırılan 18 binin üzerinde makale var.

Ancak, bu makalelerin yayından/dergiden kaldırıldıktan sonra atıf almaya devam etmesi gibi ilginç bir durum da var. 82 makale yayından kaldırıldıktan sonraki yıllarda 733 olumlu atıf alabiliyor (Pfeifer vd., 1990); Kochan ve Budd (1992): 1982 'de yayından kaldırılan Darsee'nin makalesi 1990 yılına kadar aldığı atıf 328; Budd vd., (1999): 235 makale yayından kaldırıldıkları sonra aldığı atıf 2034; Bornemann-Cimenti vd., (2015): Reuben'in 25 makalesi yayından kaldııılıktan sonraki 5 yıl içinde aldığı atıf 274; 2018 de kaldırılan bir makale kaldııldıktan sonra 371, 2007 de yayından kaldırılan makale kaldırıldıktan sonra 1096 atıf alabiliyor. En son ise Gastronomi alanında tanınmış, Cornell Üniversitesindeki "Yemek Psikolojisi Laboratuvarının" kurucusu, bilinçli beslenmenin gelişmesinde tanınmış bilim insanlarından, çalışmalarıyla medyada ve gazete köşelerinde sıklıkla kendine yer bulan 1993 den bu yana 919 yayınla h-index 83, i10-index 273 ve 31605 alıntılanması olan, olaydan sonra zorunlu olarak emekliliğe ayrılan Brian Wansink vakası (Munafo, Hollands ve Marteau, 2018). Wansink'in yaklaşık iki düzine makalesi yayından çekildi. Neden makaleler yayından kaldırılıyorlar? Nedenler çok değişik; ancak, "p korsanlığı" önde gidiyor: Psikoloji alanında incelenen 250 araştırmanın \%12 yanlış p-(olasılık) değeri sunmuş (Bakker ve Wicherts, 2011); ABD üniversitelerine araştırmaya dahil olan 2155 araştırmacının \%22'si $p$ değerini yuvarladıklarını itiraf etmiş (John vd., 2012); Alman Üniversitelerinde psikoloji alanından akademisyenlerin \%47'si hipotezi bulguları değerlendirdikten sonra oluşturduğunu itiraf etmiş (Fiedler ve Schwarz, 2015).

Adil oyun alanı olan alıntılama hızla adil olmayan bir manipülasyon alanına dönüşmekle birlikte dergi-dergi, editör-yazar, hakem-yazar, yazar-yazar arası karşılıklı/zorunlu alıntılamayı eleştiren çalışmaların sayısı da giderek artmakta. Çalışmalar neredeyse her beş makalenin en az birinde hakemin kendi makalesinin dahil edilmesini (\%20) kibar bir zorlamayla belirtmekten çekinmediğini, dergide yayınlanabilmesi için yazarların en az \%50'sinin o dergiden yersiz alıntılanma yaptığını gösteriyor (bakınız Wilhite ve Fong 
(2012) ve Fong ve Wilhite (2017), karteller hakkında daha fazla bilgi için Fister vd., (2016)).

Ayrıca dergilerin içindeki atıf dağılımı genellikle çarpık; dergi etki faktörü alana özgü; birincil araştırma makaleleri ve derlemeleri de içeren, birbirinden oldukça farklı çeşitli makale türlerinin birleşik bir ölçümü; Editoryal politikalar aracılığı ile dergi etki faktörleri manipüle edilebilir (veya etki faktörü ile oyun oynanabilir); Dergi etki faktörlerini hesaplamak için kullanılan veriler ne şeffaf, ne de herkes tarafından erişilebilir durumda değilken dergi etki faktörünün güvenilir olduğunu kabul etmek mümkün mü (Dora deklarasyonu)? Basitçe bir yıl içinde yapılan alıntılamanın belirlenen zaman dilimi içinde dergide yayınlanan makale sayısına bölünmesiyle elde edilen dergi etki faktörü çok tartışma yaratan enflasyon hesaplaması gibi değil mi? Dergide yayımlanan her makalenin aynı oranda alıntılama başarısı göstermeyeceği de kesin. Bir kaç makale illaki başı çekecektir. Bu da karşımıza normal olmayan, çarpık bir dağlım getirecektir.

Normal olmayan dağılımla normal bir başarı değerlendirmesi nasıl yapılır?

\section{Çalışmanın Kalitesi}

Yüksek sayıda alıntılanma neyin göstergesi ve neyin sonucu olabilir? Bilim insanının ve yaptığı işin kalitesinin göstergesi olduğu düşünülmekle birlikte diğer destekleyici kanıtlar olmaksızın tek başına alıntılama sayısının çalışmanın ve bilim insanının değeri hakkında net bir şeyler söyleyebilmesi neredeyse imkansız. Alıntılanan çalışmanın iş hayatında ve bilimsel dünyadaki yansıması, her ne kadar katılmasam da alıntılanan bilim insanının varsa aldığı ödüller, teşvikler, araştırma fonları, sponsor ilişkileri, meslektaşlarının hakkında düşündükleri vb çok sayıda başka kriterler de var (Cronin, 2005a, b). Araştırmanın kalitesi tek boyutlu bir kavram değil. Salt alıntılanma sayısı araştırmanın sosyal değeri, katkısı, orijinalliği, yapılabilirliği ve sağlamlığı hakkında pek de bir şey sunamıyor. En basit ve en ekonomik yaklaşımla alıntılanma sayısını saymak ve sayıları toplayarak bilim insanı ve çalışması hakkında bir şeyler söylemek tartışmalı bir yaklaşım.

Ayrıca alıntılanma motivasyonu standart formüle edilebilir bir yapıya henüz sahip değil. "Alıntılanmama" da sonsuz değil. Robinson-Garcia vd. (2015) sosyal bilimlerde yayınların \%88.1'inin hiç alıntılama almadığını belirtse de "Uyuyan Güzel" sendromlu makaleler uzunca süre hiç atıf almayan çalışmaların asla atıf almayacağı mitini yerle bir ediyor. Bu tür makaleler uzun zaman atıf almıyor görünseler de birden sihirli bir öpücükle uyanıyor ve hiç olmayan bir hızda atıf alabiliyorlar (Van Raan, 2005 a, b). Atıf sayısını etkileyebilecek çok sayıda değişken var. Bazı disiplinlerde son 15 yıl gibi yakın tarihi alıntılama eğilimi daha yüksek, bazı alanlarda ise eski tarihli makaleler daha yoğun alıntılanma yaşıyor. Mağazalarda göz hizası yerleştirmede olduğu gibi makalenin dergide kaçıncı sırada yayınlandığı dahi alıntılanma olasılığını etkileyebiliyor. İlginç ama birinci sırada yayınlanan çalışmanın son sırada yayınlanan çalışmaya göre alıntı alma intimali daha yüksek (Ayres ve Vars, 2000). Makalenin içeriği kadar makalenin sayfa uzunluğu ve referansların sayısı alıntılanma sayısını etkiliyor. Kısa makaleler ve referanslar uzun makalelere göre daha az alıntılanıyor (Beaver, 2004). Erkekler kadınlara göre daha fazla alıntılanıyor. Ayrıca yayın dünyasındakilerle var olan güçlü kişisel network alıntılanmanın zamanla artmasına neden olabiliyor (Cronin, 2005a, b).

\section{Atıf Motifi ve Davranışı}

Alıntılanma motivasyonunda genel çerçeve "kanıt sunarak ikna etmek". Mevcut yaygın bilgiye karşı meydan okumayı sağlamlaştırma, yöntemi destekleme, alan yazın 
okumasına tarihsel delil olarak sunma, öncekileri eleştirme, kendinden önce açılan patikayı takip etme gibi bir sürü alıntılama motifi mevcut.

Alıntılayanların davranışlarına baktığımızda genelde üç tür davranış öne çıkıyor: Öncekini onaylama, onaylamama ve nötr ya da kayıtsızlık hali. Eleştirel bir çalışmanın çok yaygın bir teoriyi çürüttüğünü varsayın. Atıfla onaylayanlar bu çalışmanın eleştirel argümanlarını kabul edip yaygın teorinin yanlış olduğunu tekrarlayacaklar, onaylamayanlar ise yaygın teorinin prensiplerinin doğru olduğunu savunmak için çalışmayı alıntılayacaklardır. Kayıtsızlar ise muhtemelen bir görevi tamamlamakta etkili olan "en az çaba ilkesi" gereği çalışmayı okumadıkları için ya da okudukları halde anlamadıkları için çalışmayı teoriyi teyit eden çalışma olarak alıntılayacaklardır. Bu arada içerikle uyumlu olmayan Trojan türü alıntılama da dikkate alınmalı. Editör ya da hakemi memnun etmek, gözünü boyamak, çalıntı imasından kurtulmak için ilgili makalenin çalışmada sadece bir yerde dahil edilmesi makale değerini saptırıcı bir eylem.

Alıntılama davranışında daha çok öncekini onaylama mevcut. Onaylama davranışının hakimiyeti \%10 ila \%90 arasında değişiyor. Ancak, onaylama davranışında menfaat güdümlü şöyle bir paradoks ortaya çıkıyor. Alıntılayan aynı zamanda alıntılanmak istediği için alıntıladığı çalışmanın alıntılanmasına muhtaç. Bu durumda alıntılayanın kendi çalışmasının onaylanması için alıntıladığı makaleye uyum göstermesi, (fikri, teorik çerçeve, yöntemsel yaklaşım ve bulgular) tabiatıyla onu onaylaması gerekiyor. Oysaki bilim eleştiri olmaksınız ilerleyemiyor. Herkesin birbirini onaylamaya başladığı an bilim "patinaj" etkisine giriyor. Patinaj yönün değişmesine de neden olabiliyor.

Alıntılamada önceki çalışmayı onaylamamanın sıklığı \%5 ila \%40 arasında değişiyor. Kısaca, oransal olarak çok daha az sayıda çalışma bir öncekine karşı çıkıyor, çarpışma, meydan okuma ve rakip olma cesareti gösterebiliyor (Bornman ve Daniel, 2005, 2008). Bilim eleştiri üzerine inşa edilmesi gereken bir olguyken öncekileri eleştirme, karşı çıkmanın oranı (negatif alıntılama) \%2.4. Taşkın ve Al (2017) negatif alıntılamada araştırmacının kültürünün önemli olabileceğini gösteriyor. Türkiye'de saptanan iki bilim alanında yapılan yayınlara yönelik alıntılama davranışlarının analizinde nötr, pozitif ve negatif alıntılama oranı sırasıyla \%97.2., \%2 ve \%.08. Kısaca sadece önceki çalışmalarına adından bahsetmek ezberlenmiş herhangi bir şeyi söylemekten, malumun ilamını raporlamaktan öte gidemiyor. Letrud ve Hernes (2019)'e göre eleştirilmeden kabul edilen yanlış bilgi ne kadar yaygınsa, onu eleştirmek giderek zorlaşmakta, hatta eleştirmekten daha çok yanlış bilginin daha yaygınlaşmasına hizmet etme eğilimi artmaktadır.

\section{Alıntılamadan Önce Oku}

"Alıntılanma" alıntılanan çalışmanın okunup anlaşıldıktan sonra kullanıldığı anlamına da gelmiyor. Çok sayıda çalışma (örneğin, Eichorn ve Yancuer, 1987; Evans vd., 1990) alıntılanma yapılan çalışmanın referans bölümünde yanlış yazıldığını gösteriyor. Bu oran \%10-60 arasında değişebiliyor. Bu da alıntılama yapan çalışmanın orijinal çalışmayı okuyup okumadığı hakkında büyük bir şüphe oluşturuyor. Orijinal çalışma okunmuyor, onun yerine referansında bu önemli çalışmaya yer verenden alıntılanma yapılıyorsa o zaman orada yapılan bir yanlış, yanlışın yerleşmesini sağlıyor. Şaşırtıcı olan ise tüm yanlışların kelime kelime aynı olması! Simkin ve Roychowdhury (2002) çalışması ilginç bir şekilde alıntılama yapanların sadece \%20'sinin alıntılama yaptıkları orijinal makaleyi okuduklarını gösteriyor. Alıntı yapandan alıntı yapanların bir hataya kurban gitmeleri bu nedenle sadece an meselesi. Örneğin ilk alıntılama yapanın kendi kavrayış yeteneğiyle, imla, çeviri hatası veya anlam kaymasıyla alıntılama yapması çok muhtemel. 


\section{Amaçsız Alıntılama}

Doğrulanmış kaynak bilgi karar almada gerekli olan bir unsurken, doğrulanması yapılmamış kaynak bilginin eleştirilmeden doğrudan kabul edilmesi ve kullanılması kör inanç felsefesinin bilim gibi ana yakıtı şüphe olan bir alanda yaygın olması başı başına şüpheli bir durum. Orijinalin okunmaması orijinal makalede ileri sürülen malumatın yanlış/eksik yayılmasına ya da bozulmasına neden olabiliyor. Maslow'un herkes tarafından bilinen intiyaçlar hiyerarşisini buna bir örnek olabilir. Maslow tarafından 1943 te ilk yayımlandıktan sonra bu makaleye yaklaşık bugüne kadar 38 binin üzerinde atıf yapılmış. Maslow fikirlerini 1950 de kitaplaştırmış. Ancak özellikle 1954 ve 1967den itibaren insan intiyaçlarının 1943 makalesinde söyledikleriyle sınırlı olmadığını vurgulamış (Maslow, 1967). Hatta tabiri caizse eksik ve yanlış yaptığını defalarca ifade etmiş. Bu beş motivasyonun üstünde bir meta motivasyonun varlığından bahsetmiş; ancak, alıntılama çılgınlığı ve orijinali kontrol etme eksikliği nedeniyle beş basamaklı hiyerarşi Maslow'un kendini eleştirmesine rağmen hala doğru olarak kabul görmeye devam etmekte. Bu modelin mucidi Maslow böyle olduğuna inanmasa da. Benzer bir şekilde Fodness ve Murray (1999) tarafından geliştirilen "Turist bilgi arama davranışı" adlı makaleye son 18 yılda yapılan alıntılamalar incelenmesi sonucunda (Zarezadeh, Benckendorf ve Gretzel, 2018) alıntılama yapanların sadece \%1.7sinin Fodness ve Murray'in bir fikrini, stratejisini, önerisini test ettiğini, \%25'inin Fodness ve Murray'den sadece bir cümle ya da tümce dahil ettiğini, alıntılama yapan 175 makale içinde sadece 9 çalışmanın Fodness ve Murray'in makalesindeki en önemli kısmı alıntıladığı, hiçbirinin turist bilgi arama modelini topyekun test etmediğini ortaya koymakta. Yanlış, eksik, yanlı alıntılama bu çalışmalarla sınırlı değil. Butler (1980) tarafında geliştirilen "Yaşam Alanları Yaşam Döngüsü Modeli" çalışmasına yapılan 4200 alıntılanma üzerine araştırma yapan Wang vd., (2016) her 10 alıntıdan birinin yanlış olduğunu ortaya koyuyor. Şaşırtıcı olan başka bir diğer konu ise alıntılama körlüğü. En çok atıf alan fakat içerdikleri düzetilemez hatalardan dolayı dergilerdeki yayın listesin den geri çekilen beş makaleye atıflar bu yayınlar dolaşımdan çekilmiş olmasına rağmen hala devam etmekte. Hatta atıfların \%45'i makalenin geri çekildiği tarihten sonra oluşmuş (bu konuda çok dikkate değer bilgiler için Al ve Soydal (2015) ve Halevi ve Bar-lilan (2015)).

\section{Sonuç}

Bilimsel araştırmalarda geçmişten geleceğe köprü kurmanın, çalışmanın niteliğini ve katkısını artırmanın anahtarı olan atıf son zamanlarda harareti giderek yükselen tartışmaların ana malzemesi. Atıf bilimsel malumatın bilgiye dönüşme rotasında öncü kaşiflerin bıraktıkları ayak izleri bilgiye dönen malumatın nasıl keşfedildiğinin, nereden geldiğinin, test edildiğinin, yeniden değerlendirmelere tabi tutularak nasıl perçinleştiğinin sağlam ve güvenilir göstergesiyken nasıl oldu da böylesine ateşli tartışmaların objesi oldu? İçerdiği kavramsal, tasarımsal, yöntemsel, ölçümsel hatalardan dolayı prestijli dergilerde(SSCi), hem de sözde yüksek güvenlikli hakem değerlendirmesinden geçerek yayımlanmış çok sayıda makalenin yayından/dergiden geri çekilmeleri yapılırken, SSCI dergilerindeki bazı yayınların replikasyon (yineleme) denemelerinde çalışma sonuçlarının yüzde yüz replike edilemediği ortadayken, sosyal bilimlerde üretilmiş bilginin \%95'inin geçerliliği sorgulanırken, yayından kaldıılmış makalelerin hem de katlanan hızla hala onaylanmaya/alıntılanmaya devam etmesi nasıl açıklanabilir?

"Atıf çalışmanın kalitesinin mi yoksa çalışmayı yapan bilim insanının araştırma ve yayın eylemiyle ne kadar meşgul olduğunu göstergesi olmalı?" sorusunun tartışılması için hazırlanan çalışmanın bu ikinci kısmı alıntılama amaç, davranış ve etkilerinin titizlikle incelenmesi gerekliliğine işaret etmektedir. Alıntılanma davranışının bilimin niteliğine etkilerinin farkına varılmamasıyla tartışmalı atıf geleneğinin sorun çözmekten daha çok 
sorun yaratmaya devam edeceği öngörülmektedir. Şöyle ki; bir akademisyenin yayın/atıf sayısı ne kadar başarıyı simgeler hale gelirse, yayın/atıf sayısını artırmak için önce baskı (prim) oluşacak, akademisyenler göstergelerini iyileştirmek için şaibeli işlere bulaşacak, başarıyı simgeleyen gösterge (simulakır) faydalı bilim yapmanın/gerçeğin yerini alacak, sonuçta fasarya bir bilim doğarak, başarıyı simgeleyen göstergeyi elde etme çabası başarısı bu göstergeyle ölçülen bilimi bozarak sonunu hazırlayacaktır. Bilim uzun ve meşakkatli bir dolaşımdır, dolaşımına kötü atıf girerse Gresham Yasası gereği bu iyi bilimi dolaşımdan çıkaracaktır. Faydalı atıf geleneğindeki her bir birim azalma, Okun Yasası gereği akademisyenin/ülkenin bilime katkı yapma potansiyelinden iki birim uzaklaşmasına neden olacaktır. Dolayısıyla on şaibeli atıf eşittir yirmi birim gerçekten uzaklaşma. Akademide dolaşan atıfla kazanılan mikro ün ve prestij intiyacı, faydalı bilim yapma miktarını aşarsa prestij satanların (SSCi, SCl vb dergilerin) arzında ve türünde artış olacaktır. Atıf tek göstergedir demek, tek ölçütün üstün olduğunu ifade etmek bir tür ırkçılıktır. Bilimin sadece yüksek atıfla SSCi dergilerde güvenilir olduğu iddiası gizli bir ilahın yaratılma eylemidir. Bu ilahın akıllara durgunluk veren atıfa dayandırılan dergi etkisi, gaddar ve insan kurbanlar isteyen ilahın en önemli ayinidir. "Meşhur, ünlü" etkisiyle (Metthew yasası) sadece bilinen çalışmaları alıntılamak medeniyet değildir. Bilimde medeni olmak herkes ve her yerle diyaloğu gerektirir.

Bilim, bilim insanlarının hayata ve tesadüfe sahip çıkma kapasiteleriyle ilgilidir. Hayatta tesadüfilik, spontanlık vardır. Atıf yanlıı̆̆ı veya ırkçılığıyla bilimde rastgeleliğin, tesadüfün kaldırılması keşfin özgürlüğünün, serbestliğinin ve yaratıcılığının yok edilmesidir. En kolay olanı ölçme, en basiti ölçmeyle karakterize olmuş atıf ölçümü ve standardizasyonu, faydalı bilimin iflası olacaktır. Atıfta standardizasyon içeriği ve anlamı sıyırır atar. Buğdayın standardizasyon öyküsünde olduğu gibi. Rüşeymi, kabuğu, kepeği alındıktan sonra geriye kalan içeriğin buğdayın özüyle aynı kaldığını iddia etmek aklın iflasıdır. Hem doğada standardizasyon değil bifurkasyon hakimdir. Unutulmamalıdır. Bilimin mutlak olarak tek bağlayıcı ilkesi vardır. $O$ da iflas etmemiş tek bir kuralının olamayacağı. O nedenle gösterge olarak atıf bilimsel etki/katkıda tek gösterge olmaktan çıkacaktır. Kör inanç, kopyala ve yapıştır, en az çaba ilkesi gereğince gerçeğin peşinde yorulmama bir konfor alanı yaratmıştır Konfor beyin ve bilim için tehlikelidir. Bilimdeki en büyük konfor alanlarından biri de doğruluğu kontrol edilmemiş yanlı, yanlış, eksik, yüzeysel, anlamsız alıntılamadır.

\section{Malumun yeniden ilama intiyacı yoktur!}

Araştırmacılar atıf kadar çalışmanın yaşam amacına da (raison d'etre) dikkat etmelidir. Yaşam amacını sunamayan, hele hele bunun farkında olmayan araştırma kafa karıştıracaktır. Meydan okuyan, bilinenin ötesine geçen, sınırları zorlayan, yeniliklerle merakı kamçılayan, yapılabilirliğiyle şaşırtan çalışmalar başka bir hevesle okunacaktır. Bilinirlik denizinde yüzmeyen, olgunlaşmış, artık dalından neredeyse düşecek konuları çalışmayan, yanı başındaki kolaylığı seçmeyen araştırmalar dikkat çekecektir. Çalışmanın oturduğu teorik çerçeve sağlamsa ve araştırmacı ondan öncekilerin söylediklerine yetinmemiş ve yararlandığı kaynakların orijinallerini bulup okuduysa, öncekileri alıntılamanın teori geliştirmekle eşdeğer olmadığını bilen çalışmalar takdir görecektir. İlk okunduğunda anlaşılacak kadar açık, malumun ilamı olmayan konunun farklı yönleri gösteren, bilinen varsayımları alt üst eden, çınlama yanılgısından ve yaygın yöntem yanılgısından uzaklaşmış, numaracılık sanrısından kurtulmuş, sayılara tapmayan araştırmalar turizmde geleceğin umududur. Gelecek yıllarda konusuyla alakalı ilginç, dikkat çekici, hayattan, gerçek bir hikaye, anekdot, alıntı ya da analojiyle başlayan; kanıtlamak istediği iddiasını, tezini, argümanını kendi diliyle cesurca ait olduğu zemine oturtan ve başkasının değil kendi sesiyle dile getiren; ana argümanı alt argümanlara bölebilen ve her alt argümanı destekleyen kanıtlanabilir kanıtlar sunan; 
argümanına karşı olası eleştirileri kapsamlı şekilde dile getirip bu savları çürüten; yapılabilecekleri mantık ve olabilirlik sınırları ve sırası içinde ele alan argümanı sağlam çalışmaların yeniden vücut bulacağına inanıyorum. Savrulan tartışmaları, dağınık bulguları, esasında konuyu dengeye getirirken kendine özgü bir ifade tarzı sergileyen; okurken okuyucuda konuyla, kavramla, teoriyle, uygulamayla ilgili zihinsel dönüşüm yaşatan; konunun derinliğinde gizli kalmış, keşfedilmemiş manaları okuyucunun anlamasını sağlayan bir gelişim yolculuğuna çıkaran; sınırlarının farkında olan, korunaklı, sağlam ama bir o kadar da kendine ait olanı içine alıp olmayanı dışında tutan; konuyla, yaşamla, biliş, duygu ve ruhsal düzeyde bağlantı kurduran; zeka, yaratıcılık, muhakeme gücüyle parlayan; okuyucunun görme ve yorumlama yeteneğine hükmetmeye kalkmayan, okuyucunun bilme, öğrenme ve anlamadaki kişisel hakkına tecavüz etmeyen çalışmaların sayısının artacağına inanıyorum.

Atıf almak ve saymakla yarışa dönen bilim, daha ünlünün daha da ünleneceği gerçeği (Matthew etkisi - birikmiş üstünlük) sahip olduğu ekonomik, sosyal kapital ve ilişki ağı gücüyle daha fazla güç (alıntılama- kazanma) gibi nedenler kaçınılmaz olarak bir atıf borsası yaratacaktır. Makalenin alıntılanma sayısının artmasına doğal olmayan yollardan müdahaleyi amaçlamış ilişki ağlarının oluşmasına daha da olanak verecektir. Bazı "kuzen" dergiler, editörler, hakemler ve yazarlarca yapılan tartışmalı "sen benim sırtımı kaşı ben de senin" tarzı ilişkiyi yönetecek karteller akademik camiada daha fazla boy gösterecektir. Ancak, bilim üretme makinasının çıktısını fasarya hale getiren bazı dergi ve editörlerin yapageldikleri kasıtlı suiistimaller başka bir çalışmada ele alınacak olsa da SSCi gibi dayatmalarla bir "işletme" hüviyetine bürünmüş, kurumsallaşmış bilimde bürokrasi makinası, bürokraside memurlaşan biz akademisyenler, bölünerek artan dergi sayısı, farklılaşma adına yola çıkan ancak giderek birbirine benzeyen dergilerde birbirine benzer makalelerin yer alıyor oluşu "dergitoloji" biliminin yakın zamanda yayın rafında yerini alacağına işaret ediyor. Tavşandan sonra üreme potansiyeli en yüksek varlık olan sözde bilimsel yazılara yer veren yayınevlerinin ya da dergilerin başına "sorumlu", "sosyal" ya da "bilimsel" kelimelerinin getirilişi bu yayınevlerini sorumlu, sosyal ve bilimsel yapmıyor. Halihazırda varlığını sürdüren “dergitoloji” akımı büyük sermayeli dergilerin kök salmasına, büyümesine, dallanıp budaklanmasına, beraberinde çiçek açmasına, küçük sermayeli dergilerin kurumaya yüz tutmasına, ölmesine, ölürken toprağa tohumlar saçmasına, saçılan tohumlardan büyük dergilerin gölgesinde ama daha cılız dergilerin doğmasına neden olacaktır. Parkinson yasası (Parkinson, 1957) gereği hükmedilecek, ast pozisyonda tutulacak, gerektiğinde aşağılanacak ve suçlanacak yeni ve cılız dergiler hep olacaktır. Bununla birlikte "ideal dergilerin" sayısı yedi ila dokuzu geçmeyecektir. Bu dergilerdeki yayın politikasında herhangi bir bilimsel görüşün, bilim felsefesinin haklılık ya da haksızlık derecesinin dergi yayın politikaları hakkında alınan kararlar üzerinde zerre kadar önemi olmayacaktır. Politikayı belirleyen "işletilebilir, metalaştırılabilir" değişkenler olacaktır. Parkinson yasası uyarınca bilim felsefesini okumamış, bilimle uğraşmayan, topluma faydalı bilimin can çekişme sesini duyamayacak kadar sağır olan çalışanlar, bürokratlar dergi yönetiminde daha baskın güç olacaklardır. Bu bürokratlar içinde şaş kaza bilim felsefesi okumuş olanlar bulunsa bile Sayres prensibine göre diğerleriyle aralarında herhangi bir konuda yaşanacak tartışmada konunun önemiyle tarafların yaşadığı duygusal yoğunluk ters orantılı olacaktır. Yani tartışılan konu ne kadar önemsizse tarafların birbirine gösterdiği tepki o kadar yüksek olacaktır, asıl önemli konular ise tartışılmayacaktır. Konu bilim üretme makinasının işletme karlılığı açısından ne kadar önemliyse hızlıca kabule edilecek, taraflardan az tepki alacaktır. Parkinson yasası açısından bakacak olursak konuların önemiyle tartışma süreleri de ters orantılı olacaktır. O nedenle önemsiz konular, örneğin şaibeli yayıncılık iddiasıyla odağı başka dergilere yöneltme, suçlama daha yoğun tartışılacaktır. Ancak SSCì dergilerde var olan sorunlar, suistimaller tartışılmayacaktır. Hatırlanmalıdır ki geri çekilen makalelerin büyük 
bir çoğunluğu SSCi dergiler tarafından kabul edilerek yayımlanmıştır. Bilime çeki-düzen verme adı altında üst-düzey dergiler ve editörleri kendi önemlerini artırabilmek için aslında birkaç cümlede söylenebilecekleri uzatabildikleri kadar uzatacaktır. Üst düzey dergiler bilimsel araştırmaya çağ atlatacak yenilik getirmekte zorlanacaklarından, belki de gerçekte de bu amacı taşımadıklarından, kurdukları kuvvetli network ve politik ilişkilerle "böl ve yen" ya da "acizlik" stratejisi gereği şaibeli dergi silahına sarılacak, orta seviyedeki dergiler birbirlerine karşı komplolarda zaman harcayacak, en genç dergiler ise ne yapacaklarını bilmedikleri için nefes alamayacak, şaşkın şakın gezineceklerdir. Rekabet kuralları gereği sözde üst düzey dergiler kendileri hariç diğerlerinin ortalıktan tasfiyesini, ileride kendine rakip olabilecekler ile ilgili her türlü zeka kıvılcımını kendince kurumsallaştırdığı alanın dışına itecektir.

Ancak yetmezlik evrenseldir (Laurence ve Hull, 1971). Bilim üretme makinesinin içine düştüğü hal, sürekli ve hızlı yayın yapma histerisi, mevcut gelenekteki dergilerin "yetmezlik" düzeyine ulaşma hızını artıracaktır. Yetmezlik, "kendinden bekleneni verememe" durumudur. Dergiler bilim üretiminde kendinden bekleneni veremeyecek duruma gelmektedir, gelecektir. Dergi etki faktörü, SSCi icatlarıyla kendini hiyerarşide en üst prestijli makama getiren dergiler, bir süre sonra bilime yarardan çok zarar verebilecek, eli ayağına dolaşan makinelere dönüşecektir. Bilimi yapma görevini üstlendiğini iddia eden dergiler içinde bu amaç ve uğraşta samimi istisnalar bulunsa da Peter ilkesi gereği "her görev zamanla o görevin gereklerini yerine getirmemekten aciz biri tarafından doldurulacaktır". Mevcut pozitivist gelenekte dergilerin yetmezlik düzeylerine ulaşabilmelerini hızlandıran ya da buna zemin hazırlayan uygulamalardan birinin SSCI dayatması ve İngilizce dilde yayın olduğu özellikle unutulmamalıdır. Bu arada listeden çıkarılan dergilerde körler sağırla birbirini ağırlar mantığını da savunmadığımı belirtmek isterim. Özetle, dergi etki faktörü gibi oldukça tartışmalı uygulamanın devam etmesi durumunda dergiler ve makaleler hızla kendinden bekleneni verememeye doğru gidecektir. Yayınların genelde birbirine benzemesi, yayınlarda geri çekilme oranlarının artması, istatistiklerdeki suiistimallerin yükselmesi, dergiler ve kişiler arası atıf ilişkilerinde şaibeli işlere bulaşma oranının artması, yayından kaldırılan makalelerin yayında oldukları dönemden daha yüksek sayıda atıf alması, üst-düzey dergilerin kendilerini aşırı yeterli görerek kendilerini putlaştırması bilim üretme makinasında yetmezlik düzeyine erişilmekte olduğunun bir işareti olarak yorumlanabilir. Ancak, mevcut bilim üretme makinası yetmezlik düzeyine varmak üzere olduğundan habersiz görünmektedir.

Akademiye "atıfla" musallat olan mikro ün ve prestij intiyacı, faydalı bilim yapma miktarını aşarsa makyajı ıakat içi boş çalışmalarımızın arzında ve türünde artış olacaktır. Harvard Business Review Dergisinde ret oranı bu nedenle \%99'dur! SSCI endeksli dergilerde yayın yapmak her türlü takdiri hak ediyor fakat fazlasıyla da abartılıyor. Yayın yapmak meşakkatli bir iş. Araştırma yapmak, veri toplamak ve yazmak bazen işin en kolay kısmı. Önemli mesele yazılacak nitelikte (ilginç, şaşırtıcı, zorlayıcı) çalışmanın varlığı. Eğer elde nitelikli materyal yoksa o zaman yazma işi hayal gücünüzün eline kalıyor. Çok iyi düşünülmüş, araştırma sorusuna çok uygun düşen tekil değil seri bir çalışma çok ender. Bir önceki çalışmanın kusurunu gidermek için ardı ardına yapılmış bir seri çalışma. Ama yazmayı beceremedikten sonra eldeki nitelikli materyalin de bir manası yok. Ya iyi yazamadığımız için ya da yazılacak iyi araştırmalar yapamadığımız için uluslararası atıflarda bize yakışan yerde değiliz. "Bir dolgu yapalım, 10 sene idare eder" mantığının bulunduğumuz yer konusunda etkisi olduğunu düşünmekteyim. Boşluk sapta/doldur bazlı araştırma kültürü kendi ayağına dar bir ayakkabıdır. Yaygın gelenek der ki "literatürde bir boşluk bul ve onu doldur". Dişçinin dişte saptadığı ilk çürük gibi. Bulunan ve giderek oyulan boşluğa önce geçici dolgu atılır. Bir zaman sonra o çıkarılır. Yerine kurşun-civa karışımı amalgam konur. Aynı diş bir süre sonra yeniden ağrımaya başlar. 
Kurşun amalgam sağlığa zararlıdır denerek yerine dişle aynı renkte farklı içerikte amalgam konmaya başlanmadan önce diş biraz daha oyulur. İçine amalgam doldurulur. Aynı diş bir süre sonra tekrar ağrımaya başlar. Amalgamlar yetmez, doldurmalar derman olmaz olur. Diş kanal tedavisine ihtiyaç duyar. Daha da oyulur. Hissetmesin diye dişin sinirleri alınır. Kanal tedavisi beş yıl idare eder denir ama dişin çürüyeceği de söylenir. Beş yıl sonra diş çürür, ağrılar başlar. İmplant önerilir. Aynı diş tamamen çekilir, kemiğe vida atılır. Dişin özü oyula-doldurula, oyula-doldurula yok olmuşken bir sivri akıllı çıkar der ki "dişe kök hücre eklendiğinde diş kendini yeniler." İşte doldur/boşaltın sonu budur. Gerçek olan kaybedilir, yerini yapay alır. Araç amacın yerini alır. Boşluk saptamaya uğraşmak bu nedenle risklidir. Her boşluk araştırmaya, emeğe değer boşluk değildir. Boşluğu verimsizce doldurmak hedeflendikçe, o boşluğa neden olan mekanizmanın ardındaki olgu gözden kaçar. "Önceki çalışmalar yetersiz, eksik, uygulama yanlış, ampirik desteği yok, tutarsızlık dolu, orada uygulanmış bizde uygulaması yok"la boşlukları bulmaya çalışarak, zaman kaybederek etkili bir fayda üretme fırsatını niye kaçırıyoruz ki? Fayda bir çalışmanın tam da kalbi, o yoksa bilim hareket etmiyor. Özellikle var olan yaygın varsayımlara meydan okuyan fayda. O nedenle genç akademisyenlere, fark yaratmak isteyenlere "boşluklar boşuna odağınızı bozmasın, insanların sorgulamadan inandıkları, yaptıkları, yazdıkları şeylere iyi bakın" demek yerinde bir tavsiye olabilir. Asıl "boşluk" herkesin neden sorgusuz sualsiz aynı şeyi yapıyor oluşudur. Makinada seri üretime dönen malumun ilamı yerine, gelenekten ayrıl ve nasıl daha farklı düşünebileceğini keşfet. Velev ki tüm boşluklar dolu, ne yapacaksın?

\section{Kaynaklar}

Al, U. ve Soydal, İ. (2015). Bilimsel iletişimin farklı bir yüzü: Geri çekilen makaleler [The other face of scholarly communication: Retracted articles]. Içinde Prof. Dr. İrfan Çakın'a Armağan (Umut Al \& Zehra Taşkın Eds.) (ss. 22-37). Ankara: Hacettepe University, Department of Information Management.

Alrawadieh, Z. ve Zareer, A. (2019) Exploring Retraction in Tourism and Hospitality Journals. European Journal of Tourism Research 22, pp. 20-30

Archambault, É., ve Larivière, V. (2009). History of the journal impact factor: contingencies and consequences. Scientometrics, 79(3), 639-653

Ayres, I. ve Vars, F. E. (2000). Determinants of citations to articles in elite law reviews. Journal of Legal Studies, 29, 427-450.

Bakker, M. ve Wichrts, J.M. (2011). The (mis)reporting of statistical results in psychology journals. Behav Res Methods. 43(3):666-78.

Bar-llan, J. ve Halevi, G. (2017). Post retraction citations in context: a case study. https://www.ncbi.nlm.nih.gov/pmc/articles/PMC5629243/

Beaver DB (2004) Does collaborative research have greater epistemic authority? Scientometrics 60:399-408

Bornemann-Cimenti H, Szilagyi IS, Sandner-Kiesling A. (2015). Perpetuation of retracted publications using the example of the Scott S. Reuben case: Incidences, reasons and possible improvements. Science Engineering Ethics. https://www.ncbi.nlm.nih.gov/pubmed/26150092

Bornmann, L. ve Daniel, D. H. (2008). What do citation counts measure? A review of studies on citing behavior. Journal OF documentation, 64(1):45-80

Bornmann, L. ve Daniel, D. H. (2005). Selection of research fellowship recipients by committee peer review. Analysis of reliability, fairness and predictive validity of Board of Trustees' decisions. Scientometrics, 63, 297-320.

Brainard, J. ve You, J. (2018). What a massive database of retracted papers reveals about science publishing's 'death penalty'. https://www.sciencemag.org/news/2018/10/what-massive-database-retractedpapers-reveals-about-science-publishing-s-death-penalty 
Budd JM, Sievert M, Schultz TR, Scoville C. (1999). Effects of article retraction on citation and practice in medicine. Bulletin of the Medical Library Association. 87(4):437

Butler, W. R. (1980). The concept of a tourıst area cycle of evolutıon: ımplıcatıons for management of resources. Canadian Geographer., 24: 5-12.

Craig, R., Cox, A., Tourish, D. ve Thorpe, A. (2020). Using retracted journal articles in psychology to understand research misconduct in the social sciences: What is it to be done?. Research policy. 49: 1-9.

Cronin, B. (2005a) The hand of science. Academic writing and its rewards, Lanham, MD, USA, Scarecrow Press.

Cronin, B. (2005b) A hundred million acts of whimsy? Current Science, 89, 1505-1509.

Dora Decleration. https://sfdora.org

Eichorn, P. ve Yankauer, A. (1987). Do authors check their references - a survey of accuracy of references in 3 public-health journals. American Journal of Public Health, 77, 1011-1012.

Evans, J. T., Nadjarı, H. I. ve Burchell, S. A. (1990) Quotational and reference accuracy in surgical journals - a continuing peer-review problem. Journal of the American Medical Association, 263, 1353-1354.

Fiedler, K., ve Schwarz, N. (2015). Questionable Research Practices Revisited. Social Psychological and Personality Science, 7(1), 45-52.

Fire, M. ve Guestrin, C. (2019). Over-optimization of academic publishing metrics: observing Goodhart's Law in action . Giga science. 8; 1-20.

Fister I Jr., Fister I \& Perc M (2016)Toward the Discovery of CitationCartels in Citation Networks. Front. Phys. 4:49.

Fodness, D. ve Murray, B. (1999). A Model of Tourist Information Search Behavior. Journal of Travel Research, 37(3): 220-230

Fong EA ve Wilhite AW (2017) Authorship and citation manipulation in academic research. PLoS ONE 12(12): e0187394. https://doi.org/10.1371/journal.pone.0187394

Gross, P. L. K. ve Gross, E. M. (1927) College libraries and chemical education. Science, 66, 385-389.

Halevi, G. ve Bar-llan, J. (2016). Post retraction citations in context. In BIRNDL 2016 Bibliometric- enhanced Information Retrieval and Natural Language Processing for Digital Libraries (p. 23-29). Newark: CEUR

Hesselmann, F., Graf, V. Schmidt, M., ve , Reinhart. M. (2017). The visibility of scientific misconduct: A review of the literature on retracted journal articles. https://www.ncbi.nlm.nih.gov/pmc/articles/PMC5600261/

John, L. K., Loewenstein, G., ve Prelec, D. (2012). Measuring the pre- valence of questionable research practices with incentives for truth-telling. Psychological Science, 23, 524-532. doi:10.1177/ 0956797611430953

Kochan CA, ve Budd JM. The persistence of fraud in the literature: The Darsee case. Journal of the American Society for Information Science. 1992;43(7):488493.

Laurence, J. P. ve Hull, R. (1971) The Peter Principle. Londra. Pan Books Ltd.

Letrud K. ve Hernes S (2019) Affirmative citation bias in scientific myth debunking: A three- in-one case study. PLoS ONE 14(9): e0222213.

Maslow, A. H. (1967) A Theory of Metamotivation : the Biological Rooting of the ValueLife First Published October 1, Journal of Humanistic Psychology.

Munafo, M. R., Hollands, J. G. \& Marteau, M. T. (2018). Open science prevents mindless science. https://www.ncbi.nlm.nih.gov/pmc/articles/PMC6193470/

Parkinson, C. N. (1957). Parkinson's Law and other studies in administration. Cambridge Mass. Hougton Miffi Co. 
Pfeifer MP, Snodgrass GL. (1990). The continued use of retracted, invalid literature. JAMA. 263(10):1420-1423. doi: 10.1001/jama.1990.03440100140020.

Robinson-Garcia, N. , Jiménez-Contreras, E., ve Torres-Salinas, D (2015). Analyzing data citation practices using the Data Citation Index. Journal of the Association for Information Science and Technology 67(12): 1-20.

Simkin M.V. ve Roychowdhur, V.P. (2002). Read before you cite! https://arxiv.org/pdf/cond-mat/0212043.pdf

Taşkın, Z. ve Al, U. (2017). A content-based citation analysis study based on text categorisation. Scientometric.114 (1): 335-357.

Van Raan, A. F. J. (2005a) Fatal attraction: conceptual and methodological problems in the ranking of universities by bibliometric methods. Scientometrics, 62, 133-143.

Van Raan, A. F. J. (2005b) For your citations only? Hot topics in bibliometric analysis. Measurement: Interdisciplinary Research and Perspectives, 3, 50-62.

Wang, X., Weaver, D., Li, X., ve Zhang, Y. (2016) In Butler (1980) we trust? Typology of citer motivations.

from: https://www.researchgate.net/publication/305698277_In_Butler_1980_we_ trust_Typology_of_citer_motivations[accessed Feb 10 2020].

Wilhite $\overline{A W}$ ve Fong $\bar{E} A$. (2012). Coercive Citations in Academic Publishing. Science 2012; 3 Feb:542-543. pmid:22301307

Zarezadeh, Z., Benckendorff, P. ve Gretzel, U. (2018). Lack of progress in tourist information search research: a critique of citation behaviour and knowledge development, Current Issues in Tourism, DOI: 10.1080/13683500.2018.1459511 